\title{
Societal Risk Perception Among African Villagers Without Access to the Media
}

\author{
Lonzozou Kpanake, ${ }^{1}$ Bruno Chauvin, ${ }^{2}$ and Etienne Mullet $^{3 *}$
}

\begin{abstract}
The impact of the media on people's risk perception was assessed by comparing risk ratings obtained from African villagers without access to the media with risk ratings obtained from African city-dwellers with access to the media and risk ratings obtained from French participants. The overall mean risk judgment observed among the Togolese villagers was lower than the mean rating observed among the Togolese city-dwellers, and lower than the mean rating observed among the French. The linear association observed between the Togolese villagers' ratings and the Togolese city-dweller ratings and the French ratings was moderate. The impact of the media on risk perception was estimated to be an increase of about $15 \%$ of the overall mean ratings, and to about $31 \%$ of the variance of the mean ratings. This impact was independent of educational level.
\end{abstract}

KEY WORDS: France; media coverage; risk perception; Togo

\section{INTRODUCTION}

Studies on societal risk perception by Slovic et al. (1985) have been the impetus for numerous similar investigations in a variety of countries, in Africa (e.g., Ahmed et al., 2006; Koné \& Mullet, 1994), in Asia (e.g., Cha, 2000; Neto \& Mullet, 2001), in Europe (Goszczynska et al., 1991; Karpowicz et al., 1993), in Latin America (e.g., Nyland, 1993), and in Oceania (Finucane \& Maybery, 1996). As most of these studies used questionnaires that were similar to the one used by Slovic et al. (1985), and as most of these studies included samples of students, multiple crosscountry comparisons have been made possible.

These comparisons have shown that mean risk ratings, that is, overall level of concern with soci-

\footnotetext{
1 Mirail University, Toulouse, France.

2 University of Nantes, France.

3 Institute of Advanced Studies (EPHE), Paris, France.

* Address correspondence to Etienne Mullet, Quefes 17 bis, F-

31830 Plaisance du Touch, France; tel: +33 5610753 01; fax:

+33 5614371 74; etienne.mullet@wanadoo.fr.
}

etal risk, may vary considerably from one country to another (Mullet et al., 2005). Overall mean ratings, computed over common subsets of items, ranged from about 20 (Mechitov \& Rebrik, 1990) to more than 50 (Neto \& Mullet, 2001; Nyland, 1993) on a 101-point scale. These studies have also shown that associations (linear correlations) between these ratings, that is, similarity-dissimilarity of rankings between countries, were equally variable. Overall correlation coefficients computed over common subsets of items ranged from about 0.15 (between ex-USSR and Macao) to about 0.90 (between Norway and Sweden).

When the differences in means and the differences in associations are both taken into account, five groups of countries can be distinguished: (a) a USA-Western Europe eight-country group that is composed of the United States, France, Portugal, and Italy (e.g., Savadori et al., 1998), to name a few, and that has mean values around 40/100, (b) an ex-Communist countries group (very low means - around 20/100 - and low-to-moderate linear association with the eight-country group) that is 
composed of the USSR (Mechitov \& Rebrik, 1990) and Hungary (Englander et al., 1986) (before the fall of the wall), and possibly also Bulgaria and Romania (Sjöberg et al., 1996), (c) a Scandinavian group (low means - about 30/100 - and high linear association with the eight-country group) that is composed of Norway, Finland, and Sweden (Teigen et al., 1988), (d) a Hong-Kong-Macao-Korea-Brazil group (very high means - higher than 50/100--and high linear association with the eight-country group, (Keown, 1989; Nyland, 1993), and (e) an Arab group (high means and moderate linear association with the eight-country group) that is composed of Egypt and Kuwait (e.g., Ahmed et al., 2006).

\subsection{The Media Coverage Hypothesis}

One plausible hypothesis for these cross-country differences in magnitude judgments and in rankings is related to the role of the media (Combs \& Slovic, 1979). The media coverage hypothesis states that risk perception among citizens of any country is largely determined by the media information policy in that particular country.

In regard to the differences in the media information policy between the ex-Communist group and the others, it should be mentioned that in the former Communist-bloc countries, the media rarely reported accidents (Goszczynska et al., 1991; Sjöberg et al., 1996). For example, the Russians and the Ukrainians were among the last informed about the Chernobyl nuclear accident. By contrast, accidents have always been systematically reported in countries such as the United States, Spain, France, or Italy (Savadori et al., 1998).

In regard to the differences in the media information policy between the Scandinavian group and the others, Nyland (1993, pp. 46-47) mentioned that: "Swedish television seems to emphasize problems, wars, violence, deaths, and social convulsions taking place in different parts of the world outside Sweden. As a matter of fact, Swedish people do not suffer due to social convulsions and armed confrontations, but it should be fair to say that accidents and violence happen also in Sweden, and that this aspect is usually not present in the news ... Swedish television does not usually focus on events taking place in their own police stations and emergency rooms. Since they do focus on other people's miseries and misfortunes, the impression left may be that bad things only happen outside Swedish borders." As shown by Heath (1984), the more the media report crimes in other places, the more secure readers feel in their own environment. By contrast, accidents occurring inside the country are the main focus of television in countries like Brazil, France, Portugal, and the United States.

In regard to the differences in the media information policy between the Hong-Kong-Macao group and the other groups, Neto and Mullet (2001, p. 66) mentioned that in Macao the way the media reports violence is very stark: "The criminal activities are always extensively covered by the media. In fact, on some occasions, the public has criticized reporters for displaying shocking photographs, which could upset the more sensitive readers."

Finally, the differences in the media information policy between the Arab group and the other groups may be explained by the existence of independent and powerful Arab press agencies (e.g., Kuwait News Agency, KUNA, Maghreb Arab Press), and independent Arab TV channels (e.g., Al Arabia, Al Jazirah). These media tend to report news in a way that is somewhat different from the way news is reported in countries forming the eight-country Western group.

Several studies that specifically examined the link between societal risk perception and media coverage support the media coverage hypothesis. Combs and Slovic (1979) showed that the length of articles on different types of accidents in the American press was a much better predictor of subjects' responses than official mortality figures. Nimmo and Combs (1985) asked a sample of U.S. citizens for their source of information with regard to environmental news. Seventy-three percent of the sample declared receiving all or some of the environmental news from the TV and 62\% from newspapers (see also Greenberg et al., 1989, for a complete analysis of network television news coverage).

Koné and Mullet (1994) compared ratings by inhabitants of two countries very different in terms of geography, economics, politics, and ethnic background, but similar in media coverage: Burkina Faso and France. Despite evident differences in the actual risks experienced by the inhabitants in these two countries, the general mean ratings were very similar and the correlation between ratings was very high. Sjöberg et al. (1996) demonstrated a clear increase in perceived risk among Bulgarian people from 1985 to 1993. This increase was associated with an increase in daily newspaper reports of accidents in Bulgaria and abroad.

Studies examining the link between media coverage and the fear of crime - a concept close to risk 
perception-have led to similar conclusions. Bernard (1992) explained seasonal variations in the fear of crime in France using the media coverage factor. During the summer, reports of crime become more prominent on French TV simply because political activity tends to decrease. This increase in media reports on crime coincides with a greater level of reported fear of crime observed during the months from June to October in comparison to the period from March to June. In another study, Williams and Dickinson (1993) demonstrated differences in the levels of fear of crime among readers of 10 different newspapers. In fact, there was a positive link between the space and prominence given to crime in each newspaper and the mean level of fear of crime observed among its subscribers. Moreover, this link appeared to be independent of the readers' demographic characteristics, which were controlled in the study.

Finally, Hermand et al. (1999), in a study reporting on mean risk magnitude judgments expressed by French participants aged 8 to 75 years, showed that a considerable proportion of children were able to estimate the risk associated with most items, and that the linear association between children's ratings, adults' ratings, and elderly people's ratings was very high. According to these authors, "the learning of the risk associated with various technologies, common in our society, is a very fast process, depending probably much more on exposure to media information and family discussions (socialization) than to exposure to everyday reality" (1999, p. 137). The same findings have been evidenced by Ahmed et al. (2006) on an Egyptian sample.

\subsection{This Study}

This study was aimed at examining the impact of the media on the way people perceive societal risk in a way that, until now, had never been implemented. In this study, two groups of participants from the same country were instructed to rate the severity of a set of hazards (e.g., nuclear power, vaccinations, motorcycles). The members of one of these groups lived in the capital city of an African country (Togo) and had daily access to the media (mainly TV, Internet, and newspapers). The members of the other group lived in small mountain communities in the northern part of the country and did not have access to the media. The villages (Lama and Tcharé) in which they lived were located $420 \mathrm{~km}$ north of Lomé (the capital city) and had neither telephone, television, newspa- per, electricity lines, water systems, nor a transportation network. There were no paved roads connecting these villages to the rest of the world.

The hypothesis was that between the ratings observed among the Togolese villagers and those observed among the Togolese city-dwellers, the differences should be much higher than the differences observed between the Togolese city-dwellers and a sample of French participants who responded to the same questionnaire (Chauvin et al., 2007). In particular, we expected that (a) the overall mean risk judgment observed among the Togolese villagers should be lower than the overall mean rating observed among the Togolese city-dwellers, and of the same order of magnitude as the one that was reported by Englander et al. (1986) who examined risk perception in a sample of Magyar participants who were, at the time of the study, relatively deprived of information about environmental hazards (see also Mechitov \& Rebrik, 1990), (b) the overall mean risk judgment observed among the Togolese city-dwellers should be of the same order of magnitude as the one observed among the French (see Koné \& Mullet, 1994), (c) the linear association observed between the Togolese villagers' ratings and the Togolese city-dweller ratings should be relatively moderate, and of the same order of magnitude as the one found between Magyar and participants from the US-Europe eight country group reported above (about 0.60), and (d) the linear association between the Togolese city-dwellers' ratings and the French ratings should be of the same order of magnitude as the one currently observed among countries forming the US-Europe eight country group reported above (about 0.85 ).

\section{METHOD}

\subsection{Participants}

The sample consisted of 341 Togolese citydwellers (202 males and 139 females), aged 16-64 years $(M=31.9)$ : 98 participants were 16 to 24 years old, 80 were 25 to 29 years old, 81 were 30 to 39 years old, and 82 were older than 40 . Ninety-seven participants had received a primary education, 162 had received a secondary education, and 75 had received a university education. Three-hundred twenty-eight participants declared watching $\mathrm{TV}$ on a regular basis; that is, at least for 10 hours a week. As compared with the general population in the town of Lomé, females were clearly underrepresented, young persons (16-29) were overrepresented, persons older 
than 30 were underrepresented, and also more educated people (secondary education and university education) were overrepresented. Except for gender, no reliable statistics were available for assessing the extent to which the sample was biased (for age and educational level). Participants were contacted during daylight hours on the main streets of Lomé (about 750,000 inhabitants), usually in the vicinity of the main open air markets, the school centers, the churches and mosques, and the post offices. The research team was composed of 17 psychology and demography students from the University of Lomé, trained in the techniques of questionnaires and working under the close supervision of one of the authors (LK). Each student was assigned one sector of the town and instructed to solicit every third passerby until 40 individuals - who were able to read a questionnaire-were contacted. The individuals approached were told that our research team was conducting a survey on risk perception and asked whether they were able to read a questionnaire. If the answer was positive, they were given some examples of the questions and shown the first page of the questionnaire. The acceptance rate was moderately high; $50 \%$ of the people contacted agreed to participate in the study. The main reasons for refusal to participate seemed to be lack of available time and lack of interest.

The sample also consisted of 304 Togolese villagers (189 males and 115 females), aged 14-70 years $(M=34.54): 70$ participants were 16 to 24 years old, 59 were 25 to 29 years old, 70 were 30 to 39 years old, and 105 were older than 40. One-hundred ninetyeight participants had received a primary education, 90 participants had received a secondary education, and 16 had received a university education. None of the participants stated that they watched TV on a regular basis. As compared with the general population, females were clearly underrepresented, but there were, however, no available statistics for assessing the extent to which the sample of villagers was biased for age and educational level. Before conducting the survey, the chiefs of Tchare $(2,300$ inhabitants) and Lama (3,500 inhabitants) were contacted by one of the authors (LK), informed of the objective of the study, and asked whether their village agreed to participate. The research team was composed of nine students in sociology and history from the University of Kara (northern Togo), trained in the techniques of questionnaires and working under the close supervision of one of the authors (LK). These students contacted the villagers through the chief's or another notable's mediation. Primary school teach- ers and master-catechists also helped at contacting potential participants. Participants were contacted during daylight hours in the marketplace, the chief's palace and courtyard, or by going from door to door. As in Lomé, the individuals approached were told (usually by the mediator) that our research team was conducting a survey on risk perception, and they were given some examples of the questions. The acceptance rate was high; $76 \%$ of the people contacted agreed to participate in the study.

\subsection{Material}

The questionnaire used was the same one used in the study conducted in France in 2004 (Chauvin et al., 2007). It was composed of 86 items taken from Slovic et al. (1985) risk questionnaire and of 55 additional items borrowed from Bouyer et al. (2001).

\subsection{Procedure}

Each (volunteer) participant responded individually and was briefed, before responding, that risk referred to the risk of being seriously ill, wounded, or dying (as in the original Slovic et al., 1985 study). They were invited to ask questions about unfamiliar terms and then asked to fill in the questionnaire. When an item did not evoke anything concrete, participants were allowed to refrain from responding. Responses were given on an 11-point scale labeled from "No risk" to "Extremely Severe risk". No time limit was imposed.

As in the Chauvin et al. (2007) study, responses were recorded in two successive steps. First, participants were asked to circle, with a black pencil, the number between 0 and 100 that best corresponded to their view. Then, the participants were allowed to change their responses using a red pencil. In particular, they were requested to try to clearly differentiate between risks. The main goal of this two-step procedure was to ensure that participants used the entire range of the response scales.

\section{RESULTS}

Mean responses to the questionnaire's risk perception items observed among the Togolese samples and the French sample are shown in Table I. For the Togolese villagers, these means ranged from 2.83 to 85.46 (out of 100 ). Items with the lowest means $(<10)$ were mineral water (bottles), acupuncture, ox meat, vaccinations, hospitals (medical care), 
prescribed drugs, homeopathic drugs, Valium, jogging, rarth-orbiting satellites, aspirin, soccer, and decorative tree lights. Items with the highest means (>60) were crime, deforestation, open-heart surgery, warfare, bacteriologic weapons, chemical weapons, nuclear weapons, and pregnancy. The overall mean computed over the 141 means was 25.18 , and the standard deviation of these means was 15.60. Among the most educated (more than 10 years of schooling) the mean was 25.28 and among the less educated the mean was 25.13. The difference was not significant.

For the Togolese city-dwellers, the means ranged from 3.78 to 89.47 . The overall mean was 38.90 , and the standard deviation of these means was 19.90 . Among the most educated (more than 10 years of schooling) the mean was 38.95 , and among the less educated the mean was 38.82 . The difference was not significant. For the French respondents, the means ranged from 8.50 to 95.55 . The overall mean was 45.61, and the standard deviation of these means was 21.22. Among the most educated (more than 12 years of schooling) the mean was 44.56 and among the less educated the mean was 46.48. The difference, although not very large, was significant, $F(1,140)=$ $58.36, p<0.001$.

An ANOVA was performed on the mean data from the three samples (village-dwellers, citydwellers, and French). The differences were significant, $F(2,280)=191.72, p<0.001$. Post hoc analyses showed that all two-by-two differences were significant, $p<0.001$. An ANOVA was also performed on the mean data from the females and the males. The differences were significant, $F(1,140)=432.02, p<$ 0.001 . The females' mean scores $(M=43.14)$ were higher than the males' mean scores $(M=37.14)$.

The linear correlations between the three series of means considered in the study were 0.75 (villagerscity-dwellers), 0.68 (villagers-French), and 0.92 (citydwellers-French). When computed over the subsamples of most educated participants, the values were $0.75,0.68$, and 0.91 , respectively. When computed over the subsamples of less educated participants, the values were $0.75,0.69$, and 0.92 , respectively.

A first stepwise regression analysis was performed with villagers' ratings as the criterion and the two other variables as predictors. When entered first, the city-dwellers' ratings explained $56 \%$ of the variance, and the French's ratings explained no additional part of variance. A second stepwise regression analysis was performed with city-dwellers' ratings as the criterion and the two other variables as predictors. When entered first, the villagers' ratings explained $56 \%$ of the variance, and the French rat- ings (entered second) explained an additional 31\% of the variance, $p<0.001$.

Main differences between the mean responses observed among the three samples are also shown in Table I. In 42 cases, the difference between villagers' ratings and city-dweller ratings was higher than 20 points. The mean of the absolute values of all the differences was $15.41(S D=10.90)$. In 71 cases, the difference between villagers' ratings and French ratings was higher than 20 points. The mean of the absolute values of the differences between the villagers and the French was $21.89(S D=13.29)$. In only nine cases, was the difference between city-dweller ratings and the French ratings higher than 20 points. The mean of the absolute values of the differences between the city-dwellers and the French was 8.47 (SD $=6.61)$.

\section{DISCUSSION}

This study examined the impact of the media on people's risk perception by comparing risk ratings obtained from African villagers without access to the media with risk ratings obtained from African citydwellers with access to the media and risk ratings obtained from French participants.

The first hypothesis was that the overall mean risk judgment observed among the Togolese villagers should be lower than the overall mean rating observed among the Togolese city-dwellers. This is what was observed, and the difference corresponded to about $15 \%$ of the length of the response scale. This hypothesis was also that the overall mean risk judgment observed among the Togolese villagers should be of the same order of magnitude as the one that was observed in a sample of Magyar participants who were also relatively deprived of information about environmental hazards. This is what was observed. The overall mean reported by Englander et al. (1986), computed over 86 items, was about 21, which is close to the mean of 25 found in this study.

The main differences observed between the villagers and the city-dwellers were about asbestos, nuclear waste, cleaning of tankers in sea, genetically engineered organisms, nuclear power plants, chemical fertilizers, surgery, nuclear waste dumping, DDT, Ecstasy, industrial smoke, nerve gas, heroin, high power transmission lines, amphetamines, and nuclear reprocessing plants. In other words, most of the important differences were indeed about hazards that are (or have been in the past) at the center of many controversies that were extensively reported by the media. Strong differences in the reverse direction 
Kpanake, Chauvin, and Mullet

Table I. Mean Level of Risk Ratings Observed Among the Togolese Villagers, the Togolese City-Dwellers, and the French: Differences Between the Three Samples

\begin{tabular}{|c|c|c|c|c|c|c|}
\hline & \multicolumn{2}{|c|}{ Togolese } & \multirow[b]{2}{*}{ French $(\mathrm{F})$} & \multicolumn{3}{|c|}{ Differences } \\
\hline & Villagers (V) & City-Dwellers (C) & & $\mathrm{V}-\mathrm{C}$ & $\mathrm{F}-\mathrm{V}$ & $\mathrm{F}-\mathrm{C}$ \\
\hline Crime & 85.46 & 83.70 & 87.08 & -1.77 & 1.62 & 3.39 \\
\hline Deforestation & 78.62 & 64.49 & 71.70 & -14.13 & -6.92 & 7.21 \\
\hline Open heart surgery & 74.31 & 72.26 & 58.75 & -2.05 & -15.55 & -13.50 \\
\hline Warfare & 71.68 & 80.12 & 82.59 & 8.44 & 10.91 & 2.47 \\
\hline Bacteriologic weapons & 65.89 & 83.17 & 92.98 & 17.28 & 27.09 & 9.81 \\
\hline Chemical weapons & 64.05 & 82.64 & 94.48 & 18.59 & 30.43 & 11.84 \\
\hline Nuclear weapons & 63.29 & 89.47 & 95.55 & 26.18 & 32.26 & 6.08 \\
\hline Pregnancy & 60.33 & 27.74 & 26.59 & -32.59 & -33.74 & -1.15 \\
\hline Antipersonnel mines & 56.81 & 81.82 & 91.01 & 25.01 & 34.20 & 9.19 \\
\hline Childbirth & 52.14 & 24.33 & 30.00 & -27.82 & -22.14 & 5.67 \\
\hline Boxing & 51.61 & 31.38 & 39.33 & -20.23 & -12.28 & 7.96 \\
\hline Handguns & 49.72 & 80.59 & 84.25 & 30.87 & 34.53 & 3.67 \\
\hline Dynamite & 49.61 & 69.12 & 79.99 & 19.51 & 30.38 & 10.87 \\
\hline Morphine & 45.43 & 59.79 & 63.64 & 14.37 & 18.21 & 3.84 \\
\hline Ecstasy & 44.41 & 78.77 & 81.58 & 34.36 & 37.18 & 2.82 \\
\hline Heroin & 43.49 & 76.16 & 87.41 & 32.67 & 43.92 & 11.25 \\
\hline Heterosexual relationships (with many partners) & 42.93 & 53.78 & 59.48 & 10.86 & 16.56 & 5.70 \\
\hline Homosexual relationships (with many partners) & 42.80 & 59.62 & 63.47 & 16.82 & 20.68 & 3.85 \\
\hline Stadiums (violence) & 41.09 & 56.86 & 51.90 & 15.78 & 10.81 & -4.96 \\
\hline Megapole (violence) & 39.44 & 37.65 & 59.85 & -1.79 & 20.40 & 22.20 \\
\hline Barbiturates & 38.72 & 58.97 & 64.44 & 20.26 & 25.72 & 5.47 \\
\hline Terrorism & 37.20 & 65.34 & 86.78 & 28.13 & 49.58 & 21.44 \\
\hline Industrial smoke & 36.35 & 70.00 & 64.98 & 33.65 & 28.63 & -5.02 \\
\hline Tobacco & 35.39 & 63.93 & 72.94 & 28.53 & 37.55 & 9.01 \\
\hline Alcoholic beverages & 34.80 & 54.25 & 56.75 & 19.45 & 21.95 & 2.50 \\
\hline Mushroom eating & 34.47 & 21.96 & 29.77 & -12.51 & -4.71 & 7.80 \\
\hline Nuclear waste dumping & 34.47 & 71.32 & 80.82 & 36.85 & 46.34 & 9.50 \\
\hline Nerve gas & 34.15 & 66.83 & 64.99 & 32.68 & 30.84 & -1.84 \\
\hline Amphetamin & 33.52 & 65.48 & 74.59 & 31.96 & 41.07 & 9.11 \\
\hline Genetically engineered bacteria & 33.49 & 42.55 & 60.63 & 9.06 & 27.14 & 18.08 \\
\hline Nuclear reprocessing plants & 32.82 & 64.19 & 76.89 & 31.37 & 44.07 & 12.70 \\
\hline Food irradiation & 32.66 & 54.16 & 67.64 & 21.50 & 34.97 & 13.47 \\
\hline Mountain climbing & 32.34 & 33.20 & 51.92 & 0.86 & 19.59 & 18.73 \\
\hline Supersonic aircraft & 31.88 & 36.99 & 40.82 & 5.11 & 8.94 & 3.83 \\
\hline Nuclear waste & 31.61 & 77.36 & 86.83 & 45.75 & 55.22 & 9.47 \\
\hline Marijuana & 31.41 & 45.19 & 63.13 & 13.78 & 31.72 & 17.94 \\
\hline Chemical plants & 31.15 & 54.72 & 68.92 & 23.57 & 37.77 & 14.20 \\
\hline Giant tankers & 31.12 & 59.45 & 63.47 & 28.33 & 32.35 & 4.02 \\
\hline General aviation & 30.86 & 41.20 & 36.86 & 10.35 & 6.00 & -4.35 \\
\hline Charters & 30.64 & 40.21 & 39.04 & 9.57 & 8.40 & -1.16 \\
\hline Lead & 28.29 & 55.16 & 59.12 & 26.87 & 30.83 & 3.96 \\
\hline Petrol refineries & 28.03 & 46.36 & 52.67 & 18.34 & 24.64 & 6.30 \\
\hline Mercury & 27.97 & 49.27 & 68.00 & 21.30 & 40.03 & 18.73 \\
\hline DDT & 27.37 & 62.70 & 60.25 & 35.33 & 32.88 & -2.45 \\
\hline Chlorofluorocarbons & 26.91 & 40.65 & 47.42 & 13.74 & 20.51 & 6.78 \\
\hline Lift & 26.41 & 19.41 & 25.36 & -7.00 & -1.06 & 5.95 \\
\hline Surf & 26.28 & 30.56 & 27.91 & 4.27 & 1.63 & -2.65 \\
\hline Pesticides & 26.25 & 50.48 & 62.64 & 24.23 & 36.39 & 12.17 \\
\hline Cars & 26.05 & 38.27 & 51.09 & 12.22 & 25.04 & 12.82 \\
\hline Liquid natural gas & 25.79 & 35.10 & 41.31 & 9.31 & 15.52 & 6.21 \\
\hline High power transmission lines & 25.72 & 57.80 & 59.33 & 32.08 & 33.61 & 1.53 \\
\hline DNA research & 25.63 & 41.14 & 53.67 & 15.52 & 28.05 & 12.53 \\
\hline Police work & 25.16 & 46.33 & 44.26 & 21.17 & 19.10 & -2.07 \\
\hline Clinics (medical care) & 24.70 & 24.63 & 28.48 & -0.07 & $\underline{3.78}$ & 3.85 \\
\hline Stadium (tribunes) & 24.64 & 41.79 & 26.55 & 17.15 & 1.92 & -15.24 \\
\hline
\end{tabular}


Table I. (Continued)

\begin{tabular}{|c|c|c|c|c|c|c|}
\hline & \multicolumn{2}{|c|}{ Togolese } & \multirow[b]{2}{*}{ French $(F)$} & \multicolumn{3}{|c|}{ Differences } \\
\hline & Villagers (V) & City-Dwellers (C) & & $\mathrm{V}-\mathrm{C}$ & $\mathrm{F}-\mathrm{V}$ & $\mathrm{F}-\mathrm{C}$ \\
\hline Cleaning of tankers in sea & 24.44 & 66.10 & 80.97 & 41.66 & 56.53 & 14.87 \\
\hline Trucks & 24.34 & 41.29 & 42.52 & 16.95 & 18.17 & 1.23 \\
\hline Chemical disinfectants & 24.29 & 54.02 & 64.93 & 29.73 & 40.64 & 10.91 \\
\hline Skycrapers & 24.24 & 28.71 & 38.67 & 4.47 & 14.42 & 9.96 \\
\hline Lasers & 24.14 & 39.35 & 38.01 & 15.21 & 13.87 & -1.34 \\
\hline Space exploration & 24.11 & 31.76 & 44.36 & 7.65 & 20.25 & 12.61 \\
\hline Asbestos & 23.78 & 72.34 & 82.62 & 48.56 & 58.83 & 10.27 \\
\hline Dam & 23.16 & 31.14 & 27.35 & 7.99 & 4.19 & -3.80 \\
\hline Batteries & 22.99 & 31.03 & 42.39 & 8.04 & 19.40 & 11.36 \\
\hline Spray (cans) & 22.57 & 36.22 & 43.21 & 13.65 & 20.64 & 6.99 \\
\hline Fire fighting & 22.57 & 42.32 & 47.27 & 19.76 & 24.70 & 4.95 \\
\hline Hospital waste & 22.50 & 43.17 & 64.72 & 20.67 & 42.22 & 21.55 \\
\hline Nitrates & 21.88 & 41.94 & 54.57 & 20.06 & 32.69 & 12.63 \\
\hline Nuclear power plants & 21.15 & 61.23 & 71.02 & 40.08 & 49.87 & 9.79 \\
\hline Bicycles & 20.95 & 28.77 & 22.33 & 7.81 & 1.37 & -6.44 \\
\hline Tattoos & 20.46 & 22.08 & 31.42 & 1.62 & 10.96 & 9.34 \\
\hline Piercing & 20.34 & 22.79 & 35.28 & 2.45 & 14.94 & 12.50 \\
\hline Leaded gas & 20.23 & 36.28 & 50.28 & 16.05 & 30.05 & 14.00 \\
\hline X-rays & 20.20 & 28.97 & 46.34 & 8.78 & 26.14 & 17.37 \\
\hline Genetically engineered organisms & 19.84 & 60.97 & 61.64 & 41.13 & 41.80 & 0.67 \\
\hline Gas furnaces & 19.74 & 35.54 & 41.79 & 15.81 & 22.05 & 6.24 \\
\hline Skateboards & 19.67 & 23.02 & 23.82 & 3.35 & $\underline{4.15}$ & 0.80 \\
\hline Surgery & 19.51 & 56.69 & 40.10 & 37.18 & 20.59 & -16.59 \\
\hline Recreational boating & 19.41 & 24.96 & 26.87 & 5.55 & 7.46 & 1.91 \\
\hline Cadmium (batteries) & 19.41 & 39.27 & 42.92 & 19.86 & 23.51 & 3.65 \\
\hline Fuel oil & 19.14 & 30.32 & 46.57 & 11.18 & 27.42 & 16.24 \\
\hline Fireworks & 18.82 & 31.64 & 37.48 & 12.83 & 18.67 & 5.84 \\
\hline Cement factories & 18.59 & 26.39 & 34.54 & 7.81 & 15.96 & 8.15 \\
\hline Food preservatives & 18.42 & 26.34 & 30.38 & 7.92 & 11.96 & 4.04 \\
\hline Downhill skiing & 18.32 & 27.33 & 32.44 & 9.01 & 14.12 & 5.11 \\
\hline Railroads & 18.26 & 35.16 & 28.29 & 16.90 & 10.03 & -6.87 \\
\hline Crane & 18.16 & 23.55 & 30.53 & 5.39 & 12.37 & 6.98 \\
\hline Oral contraception & 17.97 & 20.48 & 24.64 & 2.51 & 6.67 & 4.17 \\
\hline Schooling (violence) & 17.76 & 26.69 & 44.77 & 8.92 & 27.01 & 18.08 \\
\hline Thermal power plants & 17.76 & 30.91 & 43.67 & 13.15 & 25.91 & 12.76 \\
\hline Chemical fertilizers & 17.76 & 56.25 & 66.21 & 38.49 & 48.45 & 9.96 \\
\hline Motorcyles & 17.60 & 45.19 & 43.03 & 27.59 & 25.43 & -2.16 \\
\hline Wind energy & 17.43 & 24.05 & 10.84 & 6.61 & -6.59 & -13.20 \\
\hline Hunting & 17.27 & 21.64 & 47.75 & 4.37 & 30.48 & 26.11 \\
\hline Diving & 17.14 & 24.60 & 36.09 & 7.47 & 18.95 & 11.48 \\
\hline Herbicides & 16.91 & 45.78 & 51.72 & 28.87 & 34.82 & 5.95 \\
\hline Hydroelectric power plants & 16.78 & 28.12 & 33.03 & 11.35 & 16.26 & 4.91 \\
\hline Sunbathing & 16.59 & 20.50 & 48.40 & 3.91 & 31.81 & 27.90 \\
\hline Home power tools & 16.22 & 22.02 & 27.36 & 5.81 & 11.14 & 5.34 \\
\hline Excess food consumption & 15.89 & 36.98 & 57.22 & 21.09 & 41.33 & 20.24 \\
\hline Food stains & 15.72 & 21.96 & 33.06 & 6.24 & 17.33 & 11.09 \\
\hline Power mowers & 15.53 & 20.76 & 27.92 & 5.24 & 12.40 & 7.16 \\
\hline Swimming pools & 15.53 & 28.01 & 30.79 & 12.48 & 15.27 & 2.79 \\
\hline Air conditioning & 15.34 & 24.11 & 32.58 & 8.77 & 17.24 & 8.47 \\
\hline Cosmetics & 15.23 & 21.06 & 20.23 & 5.83 & 5.00 & -0.83 \\
\hline Water fluoridation & 15.13 & 27.98 & 34.06 & 12.84 & 18.93 & 6.09 \\
\hline Bridges & 14.18 & 19.97 & 19.81 & 5.79 & 5.63 & -0.16 \\
\hline Microwave ovens & 14.18 & 25.34 & 30.98 & 11.16 & 16.80 & 5.64 \\
\hline Computer screens & 13.98 & 19.59 & 31.30 & 5.61 & 17.32 & 11.71 \\
\hline Antidepressants & 13.95 & 18.72 & 52.33 & 4.78 & 38.38 & 33.60 \\
\hline Public buildings & 13.79 & 20.39 & 18.39 & 6.60 & 4.60 & -2.00 \\
\hline
\end{tabular}


Table I. (Continued)

\begin{tabular}{|c|c|c|c|c|c|c|}
\hline & \multicolumn{2}{|c|}{ Togolese } & \multirow[b]{2}{*}{ French $(\mathrm{F})$} & \multicolumn{3}{|c|}{ Differences } \\
\hline & Villagers (V) & City-Dwellers (C) & & $\mathrm{V}-\mathrm{C}$ & F-V & F-C \\
\hline Caffeine & 13.55 & 26.63 & 27.55 & 13.07 & 13.99 & 0.92 \\
\hline Heating covers & 13.52 & 19.59 & 27.90 & 6.07 & 14.38 & 8.31 \\
\hline Anesthetics & 13.43 & 19.74 & 47.04 & 6.31 & 33.62 & 27.31 \\
\hline Radiotherapy & 13.16 & 24.11 & 34.24 & 10.95 & 21.08 & 10.13 \\
\hline Public transportation & 13.13 & 32.35 & 23.77 & 19.23 & 10.65 & -8.58 \\
\hline Farming (massive irrigation) & 12.93 & 16.36 & 33.65 & 3.44 & 20.72 & 17.28 \\
\hline Saccharin & 12.50 & 19.97 & 22.52 & 7.47 & 10.02 & 2.55 \\
\hline Sleeping pills & 12.50 & 34.05 & 48.74 & 21.55 & 36.24 & 14.70 \\
\hline Solar power plants & 12.27 & 20.75 & 20.62 & 8.48 & 8.35 & -0.13 \\
\hline Cleansers & 12.27 & 22.59 & 21.60 & 10.32 & 9.33 & -0.99 \\
\hline Antibiotics & 11.97 & 16.45 & 35.25 & 4.48 & 23.27 & 18.79 \\
\hline Hair dyeing & 11.91 & 16.33 & 19.70 & 4.42 & 7.79 & 3.37 \\
\hline Blood transfusions & 11.51 & 34.08 & 41.86 & 22.57 & 30.35 & 7.78 \\
\hline Tranquilizers & 11.41 & 24.08 & 48.75 & 12.66 & 37.34 & 24.68 \\
\hline Plastic food containers & 11.02 & 22.38 & 16.99 & 11.36 & 5.97 & -5.38 \\
\hline Tractors & 10.69 & 23.90 & 27.28 & 13.21 & 16.59 & 3.38 \\
\hline Home appliances & 10.56 & 15.84 & 15.93 & 5.28 & 5.37 & 0.10 \\
\hline Decorative tree lights & 9.93 & 12.42 & 15.16 & 2.49 & 5.22 & 2.74 \\
\hline Soccer & 9.44 & 19.91 & 19.71 & 10.47 & 10.27 & -0.20 \\
\hline Aspirin & 8.52 & 15.69 & 21.40 & 7.17 & 12.88 & 5.71 \\
\hline Earth-orbiting satellites & 8.29 & 20.94 & 26.11 & 12.65 & 17.82 & 5.17 \\
\hline Jogging & 8.22 & 12.82 & 12.45 & $\underline{4.59}$ & $\underline{4.23}$ & -0.36 \\
\hline Valium & 7.66 & 30.91 & 49.74 & 23.24 & 42.07 & 18.83 \\
\hline Homeopathic drugs & 7.63 & 9.97 & 12.24 & 2.34 & $\underline{4.61}$ & 2.27 \\
\hline Prescribed drugs & 7.53 & 20.47 & 26.73 & 12.94 & 19.20 & 6.26 \\
\hline Hospitals (medical care) & 7.37 & 28.94 & 31.56 & 21.58 & 24.19 & 2.62 \\
\hline Vaccinations & 6.25 & 16.89 & 25.25 & 10.64 & 19.00 & 8.35 \\
\hline Ox meat & 5.49 & 16.42 & 21.51 & 10.93 & 16.02 & 5.09 \\
\hline Acupuncture & 4.67 & 14.19 & 13.21 & 9.52 & 8.54 & -0.99 \\
\hline Mineral water (bottle) & 2.83 & 3.78 & 8.50 & 0.95 & 5.68 & 4.72 \\
\hline
\end{tabular}

The hazards are ordered as a function of villagers' mean risk ratings.

have also been registered about pregnancy and childbirth, two hazards that rarely capture the attention of the media.

The second hypothesis was that the overall mean risk judgment observed among the Togolese citydwellers should be of the same order of magnitude as the one observed among the French. This is also what was observed, but the overall mean observed among the French was higher; the difference was about 7 points. This finding was consistent with what was reported by Koné and Mullet (1994), who worked on a sample of participants living in Ouagadougou, the capital city of Burkina Faso.

The main differences observed between the Togolese city dwellers and the French were about antidepressants, sunbathing, anesthetics, hunting, tranquilizers megapole (violences), hospital waste, terrorism, excess food consumption, Valium, and antibiotics. In other words, most of the important differ- ences were not especially about hazards that are at the center of the debates about societal risk that are reported in the media. With regard to the many prescribed drugs that are listed above, the problem in Lomé was more about the relative lack of such substances and their cost than about their use.

The third hypothesis was that the linear association observed between the Togolese villagers' ratings and the Togolese city-dweller ratings should be relatively moderate. In fact, the correlation coefficient (0.75) was higher than expected. This is possibly due to the fact that in Togo a number of daily concerns are present to the villagers' attention in the same way as they are present to the city-dwellers' attention (e.g., medical care and drugs). By comparison, the linear association between villagers and French ratings was lower (0.68), and of the same order of magnitude as the one registered in the study by Englander et al. (1986, p. 63) between Hungary and the 
United States. In addition, the French ratings were not related to the villagers' ratings once the citydweller ratings were taken into account.

The fourth hypothesis was that the linear association between the Togolese city-dwellers' ratings and the French ratings should be of the same order of magnitude as the one currently observed among countries forming the U.S.-Europe eight country group reported above. This is what was observed. In addition, the city-dweller ratings were still related to the French ratings once the villagers' ratings were taken into account. In other words, predicting the city-dwellers' ratings required both sets of data.

Overall, it can be stated that, in this study, the impact of the media on risk perception may be estimated to be an increase of about $15 \%$ of the overall mean ratings $(15 \%$ of the length of the response scale) and to about $31 \%$ of the variance of the mean ratings. This impact was independent of educational level, that is, this impact of the media on risk perception (as regard mean levels of judged risk and as regards hazards ranking) is practically the same whether the participants have been schooled more than 10 years or not. This finding is consistent with findings by Bouyer et al. (2001) showing that educational level was not strongly associated with risk perception.

Although strong, the impact of the media was, however, not overwhelming. Between the villagers' ratings and the city-dwellers' ratings the correlation was substantial. Daily experience inevitably tells everybody, villagers as well as city-dwellers, that some activities or some substances are riskier than others. The term "weapon" used in several items (e.g., bacteriological weapons) is bound to be understood by everybody as corresponding to elevated levels of risk. As a consequence it is no wonder that all these items received the highest ratings among all groups. By contrast, the term "drinkable water" (e.g., mineral water in bottle) is bound to be understood as corresponding to very low levels of risk. As a consequence, it is predictable that this item and those that are similar to it received the lowest ratings among all groups.

In terms of overall mean ratings, if we assume that daily experience teaches us that certain things are riskier than others, then the effect of daily experience may be estimated at about 22 (the difference between the mean value observed in this study, 25, and the lowest value observed, about 3 ), and the effect of media exposure may be estimated at 13 (the difference between 38 , the mean value observed among the city dwellers and the villagers, and 25). In terms of variance, the effect of exposure to the media may be estimated at about $31 \%$ (the value found in this study), and the effect of daily experience may be estimated as the difference between the maximum percentage of variance ever observed in a risk perception study, 84\% (Mullet et al., 2005) and 31\%, that is, about $53 \%$. The part of variance that is left unexplained is about $16 \%$. These estimations are to be considered as partly speculative and are just offered as a basis for reflection and future work. These estimations are, however, consistent with af Wåhlberg and Sjöberg's suggestions (2000, p. 44) that "the media do influence our risk perceptions but they are only one factor among many," and "direct information from people about their experience is a much stronger factor, as is personal experience."

\subsection{Limitations}

The villagers who participated in the study were not only deprived of information about hazards as compared with the city-dwellers, but they were also living in an environment that was different. As an example, their access to health services was comparatively much more limited. For easily understandable reasons, it was not possible, in this study, to disentangle the media coverage factor and the daily environment factor. In fact, daily life is the villages that were selected for the study is, judging from the life expectancy statistics (World Health Organization, 2007), objectively more risky than it is in Lomé (or in France).

\section{ACKNOWLEDGMENTS}

This work was supported by the UPRES Education, Cognition, Développement (University of Nantes), the Ethics and Work Laboratory of the Institute for Advanced Studies (EPHE), the SAFE European Network, and the "Université de Toulouse" (CLLE-LTC, CNRS, UTM, EPHE). Thanks are extended to Nancy Fellicelli for her thoughtful comments on an earlier draft of this article.

\section{REFERENCES}

Ahmed, R., Macri, D., \& Mullet, E. (2006). Societal risk perception among Egyptian adolescents and adults. Journal of Northern-Africa Studies, 11, 323-334.

Bernard, Y. (1992). North American and European research on fear of crime. Applied Psychology: An International Review, $41,65-75$. 
Bouyer, M., Bagdassarian, S., Chaabane, S., \& Mullet, E. (2001). Personality correlates of risk perception. Risk Analysis, 21, $457-465$.

Cha, Y.-J. (2000). Risk perception in Korea: An application of the psychometric paradigm. International Journal of Risk Assessment and Management, 1, 42-51.

Chauvin, B., Hermand, D., \& Mullet, E. (2007). Risk perception and personality facets. Risk Analysis, 27, 171-185.

Combs, B., \& Slovic, P. (1979). Newspaper coverage of causes of death. Journalism Quarterly, 56, 837-843.

Englander, T., Farago, K., Slovic, P., \& Fischhoff, B. (1986). A comparative analysis of risk perception in Hungary and the United States. Social Behavior, 1, 55-66.

Finucane, M. L., \& Mayberry, M. T. (1996). Risk perception in Australia. Psychological Reports, 79, 13311338 .

Goszczynska, M., Tyszka, T., \& Slovic, P. (1991). Risk perception in Poland: A comparison with three other countries. Journal of Behavioral Decision Making, 4, 179-193.

Greenberg, M. R., Sandman, P. M., Sachsman, D. B., \& Salomone, K. L. (1989). Network television news coverage of environmental risks. Environment, 31, 17-20, 40-44.

Heath, L. (1984). Impact of newspaper crime reports on fear of crime: Multimethodological investigation. Journal of Personality and Social Psychology, 47, 263-276.

Hermand, D., Mullet, E., \& Rompteaux, S. (1999). Societal risk perception in adolescents, adults, and the elderly people. Journal of Adult Development, 6, 137-143.

Karpowicz-Lazreg, C., \& Mullet, E. (1993). Societal risks as seen by a French public. Risk Analysis, 13, 253258 .

Keown, C. F. (1989). Risk perception of Hong Kongese vs. Americans. Risk Analysis, 9, 401-405.

Koné, D., \& Mullet, E. (1994). Societal risk perception and media coverage. Risk Analysis, 14, 21-24.
Mechitov, A., \& Rebrik, S. (1990). Studies of risk and safety perception in the USSR. In K. Borcheding, O. I. Larichev, \& D. M. Messick (Eds.), Contemporary Issues in Decision Making. Amsterdam: Elsevier.

Mullet, E., Candela, C., Karpowicz Lazreg, C., \& Neto, F. (2005). The Scandinavian way of perceiving societal risks. Journal of Risk Research, 8, 19-30.

Neto, F., \& Mullet, E. (2001). Societal risks as seen by Chinese students living in Macao. Journal of Risk Research, 4, 63-73.

Nimmo, D., \& Combs, J. E. (1985). Nightly Horrors: Crisis Coverage in Television Network News. Knoxville, TN: University of Tennessee Press.

Nyland, L. G. (1993). Risk Perception in Brazil and Sweden. Stockholm: Rhizicon.

Savadori, L., Rumiati, R., \& Bonini, N. (1998). Expertise and regional differences in risk perception: The case of Italy. Swiss Journal of Psychology, 57, 101-113.

Sjöberg, L., Kolanova, D., Rucai, A. A., Bernström, M.-L., \& Flygelholm, H. (1996). Risk Perception and Media Reports in Bulgaria and Romania. Stockholm: Center for Risk Research.

Slovic, P., Fischhoff, B., \& Lichtenstein, S. (1985). Characterizing perceived risk. In R. Kates, C. Hohenemser, \& R. Kasperson (Eds.), Perilous Progress: Managing the Hazards of Technology. Boulder: Westview.

Teigen, K., Brun, W., \& Slovic, P. (1988). Societal risk as seen by a Norwegian public. Journal of Behavioral Decision Making, 1, 111-130.

Wåhlberg, A. F., \& Sjöberg, L. (2000). Risk perception and the media. Journal of Risk Research, 3, 31-50.

Williams, P., \& Dickinson, J. (1993). Fear of crime: Read all about it? The relationship between newspaper crime reporting and fear of crime. British Journal of Criminology, 33, 33-56.

World Health Organisation. (2007). Core Health Indicators. Available at http://www.who.int/whosis/database/core/core select _process.cfm (assessed June 28, 2007). 